\title{
Kerentanan Sosial Ekonomi dan Strategi Adaptasi Keluarga Petani Miskin Selama Pandemi Covid-19: Kasus Dari Madura
}

\author{
${ }^{1}$ Hoiril Sabariman \\ Alumni Magister Ilmu Sosial FISIP, Universitas Brawijaya \\ hoirilsabariman@yahoo.com \\ ${ }^{2}$ Anik Susanti \\ Tenaga Pengajar Sosiologi FISIP, Universitas Brawijaya \\ aniksusanti@ub.ac.id
}

Keywords:

vulnerability;

resilience; poor

farmers; Covid-19

pandemic

Kerentanan;

Strategi Adaptasi;

Petani Miskin;

Pandemi Covid-19

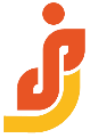

BRAWIJAYA JOURNAL of SOCIAL SCIENCE

Vol. 1 ,No. 1,2021

DOI:

https://doi.org/10.

21776/ub.bjss.202 1.001 .01 .1

Submitted:2021-11-10

Accepted:2021-12-05

\section{Abstract}

The Covid-19 pandemic, in addition its health impacts, also has a serious impact to people's socioeconomic vulnerabilities. Socio-economic vulnerabilities due to the Covid-19 pandemic forced people to adapt, one of which was a poor peasant family in rural Madura. This article presents the results of research focusing on the socio-economic vulnerability of poor peasant family as well as various efforts in dealing with the Covid-19 pandemic. Using descriptive qualitative approach and data collection method through participation observation, interviews, airy records, and documentation, this study revealed that the socioeconomic vulnerability of poor peasant family in Ponteh Village resulted from social restrictions so that the household income sector decreased. Though they have to adaptation meet the cost of household consumption, health threats in the Covid-19 pandemic. Adaptation strategy carried out by poor peasant family in rural areas is, first, building group solidarity according to values and norms that are strong, for example, mutual help in the form of basic needs. Second, every poor peasant family makes use of very strong family ties. Parental assistance as a source of supporting living is now a basic source used to make ends meet during pandemics. Third, poor peasant family in rural areas minimize household in spending and utilizing-social networks for business development. The contribution of this article is to provide views, efforts, accompanied by resilience in keeping the public from the threat of future pandemics.

\section{Abstrak}

Pandemi Covid-19 selain berdampak dalam bidang kesehatan, juga menimbulkan ancaman akut bagi kerentanan sosial ekonomi masyarakat. Kerentanan sosial ekonomi akibat pandemi Covid-19 memaksa masyarakat untuk beradaptasi, salah satunya adalah keluarga petani miskin di perdesaan Madura. Artikel ini menyajikan hasil penelitian yang berfokus pada kondisi kerentanan sosial ekonomi keluarga petani miskin serta berbagai upaya dalam 
menghadapi pandemi Covid-19. Pendekatan kualitatif deskriptif dan metode pengumpulan data melalui observasi partisipasi, wawancara, catatan lapang, dan dokumentasi, penelitian ini mengungkap bahwa kerentanan sosial ekonomi keluarga petani miskin di Desa Ponteh diakibatkan pembatasan sosial, sehingga sektor pendapatan rumah tangga menurun. Padahal mereka harus beradaptasi untuk memenuhi biaya konsumsi rumah tangga, ancaman kesehatan di masa pandemi Covid-19. Strategi adaptasi yang dilakukan keluarga petani miskin di perdesaan yaitu, pertama, membangun solidaritas kelompok sesuai nilai dan norma yang berkembang, misal contoh gotongroyong, saling membantu dalam bentuk kebutuhan pokok. Kedua, Setiap keluarga petani miskin memanfaatkan ikatan keluarga yang sangat kuat. Bantuan orang tua sebagai sumber nafkah penunjang, kini menjadi sumber pokok yang digunakan untuk memenuhi kebutuhan hidup selama masa pandemi. Ketiga, keluarga petani miskin di perdesaan meminimalkan pengeluaran rumah tangga dan memanfaatkan jaringan sosial untuk pengembangan usaha. Kontribusi artikel ini adalah memberikan pandangan, upaya, disertai dengan daya tahan dalam menjaga masyarakat dari ancaman pandemi di masa depan.

\section{Pendahuluan}

Pandemi Covid-19 yang terjadi saat ini tidak sebatas persoalan kesehatan masyarakat, namun juga merambat dalam bidang sosial, politik, ekonomi, serta kesejahteraan (Arifin, 2021). Pandemi ini tidak hanya menjadi krisis dan ancaman global, namun juga dalam ruang lingkup yang lebih kecil yaitu lingkungan masyarakat, dan kesejahteraan keluarga. Ancaman akut bagi kesejahteraan keluarga karena tantangan yang berkaitan dengan gangguan sosial seperti pembatasan sosial, ketidakamanan ekonomi, beban keluarga, dan stres terkait kurungan (misalnya, berkerumun, perubahan struktur, dan rutinitas). Konsekuensi dari kesulitan-kesulitan ini cenderung sudah berlangsung lama, sebagian karena cara-cara dimana risiko kontekstual menembus struktur dan proses sistem keluarga (Prime et al., 2020). Dimana dinamika lintas batas Covid-19 menghadirkan berbagai masalah, kerentanan sosial, ketahanan organisasi yang belum pernah terjadi sebelumnya (Bryce et al., 2020).

Selain bidang kesehatan, kelompok yang paling rentan terkena dampak dari Covid19 adalah usaha yang membutuhkan keramaian massa. Diantaranya, pedagang kaki lima, kelompok pekerja harian lepas, para buruh yang terdampak Pemberhentian Hubungan Kerja (PHK), masyarakat miskin, petani, dan seterusnya (Kurniawansyah et al., 2020). Kelompok yang paling rentan menanggung beban paling besar adalah masyarakat yang sulit terhadap akses kesehatan, sosial, dan ekonomi yaitu salah satunya petani (Penkler et al., 2020). Akibat kebijakan pembatasan sosial berskala besar, petani mengalami berkurangnya pendapatan karena hasil pertanian sulit terjual yang berpengaruh pada modal usaha tani (Pontoan et al., 2021). Kondisi penurunan pendapatan yang dialami petani selanjutnya berdampak pada kemampuan memenuhi kebutuhan dan ketersediaan pangan yang ada. Pada akhirnya mendorong petani untuk bekerja 
sampingan di luar sektor pertanian (A'dani et al., 2021). Adanya perubahan perilaku sosial di kalangan petani selama pandemi Covid-19, misal jumlah waktu yang dialokasikan untuk pertanian, modal pertanian sebelum pandemi lebih besar dibandingkan ketika pandemi Covid-19. Sedangkan pengeluaran konsumsi rumah tangga petani mengalami peningkatan (Filofa \& Yamin, 2021).

Strategi diperlukan guna meningkatkan kapasitas dan kapabilitas di sektor pertanian saat masa pandemi Covid-19. Beberapa literatur yang menjelaskan strategi guna menghadapi pandemi misal penjelasan dari Sudaryanto \& Suharyono (2020), A'dani (2021), Pontoan (2021), Darnhofer (2020), dan Satriyati (2021). Strategi dalam bidang pertanian dimulai dari individu, masyarakat, lembaga, sampai pada sistem yang ada dalam konteks masyarakat pertanian. Guna meningkatkan kapasitas dan kapabilitas dalam bidang pertanian, perlu difokuskan pada dua aspek utama, yaitu aktivitas on-farm dan off-farm meliputi penanganan pasca panen, pemasaran, hingga peningkatan kapasitas komunitas melalui modal sosial masyarakat yang berkembang (Sudaryanto \& Suharyono, 2020). Sedangkan A'dani (2021) menjelaskan bahwa diperlukan adanya berbagai pelatihan tentang pengelolaan usaha tani guna meningkatkan kemampuan rumah tangga petani menghadapi dampak yang ditimbulkan pandemi ini (A'dani et al., 2021). Sedangkan Satriyati (2021) menjelaskan tentang proses adaptasi rumah tangga petani dalam menghadapi pandemi dengan konsumsi dan memproduksi rempah sendiri yang dihasilkan dari pekarangan. Kondisi ini menjelaskan bahwa efektivitas upaya rumah tangga petani kembali ke rempah sebagai cara alternatif guna meningkatkan kesehatan dan penanggulangan kemiskinan saat pandemi Covid-19 (Satriyati \& Biroli, 2021).

Penjelasan berbeda dipaparkan oleh Pontoan (2021), dan Darnhofer (2020) tentang strategi petani dalam menyikapi pandemi Covid-19. Pontoan (2021) menjelaskan bahwa dalam menghadapi pandemi, diperlukan meningkatkan kapasitas petani dalam mengembangkan usaha pertanian. Peningkatan kapasitas lebih fokus melalui pengelolaan keuangan, modal sosial yang berkembang dalam masyarakat, serta melakukan pemasaran digital produk pertanian. Pemasaran digital merupakan tanggapan terhadap penutupan pasar akibat pembatasan sosial oleh pemerintah (Pontoan et al., 2021). Sementara Darnhofer (2020) menjelaskan berbagai petani di Austria saat menghadapi pandemi. Pada pertengahan Maret 2020 langkah-langkah radikal dilakukan guna mempengaruhi hampir semua aspek kehidupan masyarakat. Platform online digunakan untuk membangun hubungan baru, menghubungkan petani dan masyarakat. Petani yang terlibat dalam pemasaran, dapat melakukan penawaran langsung hasil pertanian kepada konsumen. Petani dapat mengirimkan pesanan hasil pertanian. Sehingga beberapa petani dapat beradaptasi, serta menunjukkan ketahanan sosial, ekonomi di masa pandemi (Darnhofer, 2020).

Menyikapi kerentanan sosial ekonomi, keluarga petani miskin dapat beradaptasi atas berbagai perubahan yang diakibatkan pandemi Covid-19. Kemampuan beradaptasi ini akan menentukan keluarga bertahan terhadap semua gangguan yang diakibatkan oleh pandemi Covid-19. Beberapa gangguan akibat pandemi, misal contoh; ekonomi, 
sosial, kesejahteraan, kesehatan dan lain sebagainya (Sunarti, 2021). Namun, beberapa masyarakat tidak terlalu mendalam atau tidak parah mengalami kerentanan sosial akibat pandemi Covid-19. Masyarakat perdesaan memiliki ikatan sosial budaya masih kokoh. Selain itu, masih mengakarnya konsep kekeluargaan yang berdasarkan kesukuan dan keagamaan. Ikatan sosial yang didasarkan kekeluargaan menjadi faktor utama penguatan relasi sosial masyarakat dalam menghadapi pandemi. Kerentanan dalam di bidang ekonomi tidak terlalu tinggi, karena perekonomian masyarakat desa masih berbasis alam seperti pertanian dan perkebunan. Didukung sistem penanganan dan penanggulangan yang cukup baik dari pemerintah setempat (Musa et al., 2021).

Kesulitan yang dihadapi masyarakat selama pandemi Covid-19, juga dialami oleh keluarga petani miskin di Madura. Kebijakan pembatasan masyarakat yang ditetapkan dan diberlakukan pemerintah selama pandemi Covid-19 memberikan beban tersendiri terhadap kerentanan sosial ekonomi keluarga petani miskin. Tujuan artikel ini adalah menganalisis dan menjelaskan kerentanan sosial ekonomi keluarga petani miskin selama pandemi Covid-19 di Desa Ponteh Kecamatan Galis Kabupaten Pamekasan. Selanjutnya adalah strategi adaptasi yang dilakukan keluarga petani miskin dalam menghadapi pandemi Covid-19 yang sedang terjadi.

\section{Metode Penelitian}

Penelitian ini dilakukan di Desa Ponteh Kecamatan Galis Kabupaten Pamekasan. Lokasi penelitian ini ditentukan dengan purposive method (Sugiyono, 2016). Desa Ponteh dipilih berdasarkan pertimbangan bahwa beberapa petani miskin dapat keluar dari kondisi sulit saat masa pandemi Covid-19. Selain itu, Desa Ponteh merupakah salah satu desa berbasis pertanian yang memiliki tingkat adaptasi terhadap pandemi Covid-19 dengan berbagai inovasi dalam bidang pertanian. Terakhir, keluarga petani miskin di Desa Ponteh masih menerapkan kesederhanaan kehidupan petani, serta kearifan lokal dalam menghadapi pandemi Covid-19.

Metode deskriptif kualitatif digunakan sebagai metode penelitian. Lima petani dari keluarga miskin sebagai informan penelitian, yang ditentukan berdasarkan pertimbangan dan kriteria tertentu. pertama; keluarga petani miskin yang memiliki beberapa inovasi dalam menghadapi pandemi Covid-19. Kedua; petani aktif dalam organisasi sosial seperti kelompok tani, koperasi tani dan sebagainya (Creswell, 2007). Penelitian ini bertujuan untuk menjelaskan dan menganalisis kerentanan sosial dan strategi adaptasi keluarga petani miskin selama pandemi Covid-19. Data primer dan data sekunder digunakan sebagai sumber data penelitian. Data primer didapat dari observasi terhadap kondisi keluarga petani miskin, wawancara, dan catatan lapangan. Sementara data sekunder diperoleh dari dokumentasi dan berbagai sumber lain, seperti arsip dan catatan lainnya.

Pengumpulan data telah dilakukan dengan cara observasi ketika keluarga petani miskin menggarap tanaman, serta ketika mengadakan pertemuan kelompok tani. Sesekali, wawancara dilakukan ketika petani sedang beristirahat. Wawancara telah 
dilakukan kepada Bapak Bambang, Bapak Affan, Bapak Samsul, Ibu Mita, serta Ibu Anik. Pengumpulan data dengan observasi dan wawancara ketika petani sedang istirahat. Kegiatan ini telah memberikan pemaparan secara mendalam tentang keadaan yang sebenarnya mengenai kondisi kerentanan sosial yang dihadapi oleh petani, serta kejelasan informasi yang didapat dan lebih mendalam tentang fenomena strategi adaptasi selama pandemi Covid-19. Wawancara terhadap informan penelitian di atas dilakukan dengan menggunakan panduan, sesuai dengan fokus penelitian yang telah ditentukan. Hasil observasi, catatan lapangan, dan wawancara yang telah diperoleh kemudian diringkas dan dibandingkan informan satu dengan yang lainnya. Saat terdapat jawaban berbeda dari informan penelitian, diidentifikasi kemudian dikoreksi sesuai dengan fokus penelitian.

Setelah data terkumpul, langkah selanjutnya adalah proses analisis data. Dalam penelitian ini, model interaktif Miles dan Huberman sebagai metode analisis data (Miles et al., 2014). Analisis data penelitian ini dimulai dengan mengumpulkan data di lokasi penelitian, baik observasi atau wawancara. Analisis ini dilakukan secara intensif dan berlangsung secara terus menerus hingga tuntas, sampai data dirasa sudah jenuh. Kegiatan ini dimulai dari reduksi data, penyajian data serta menarik kesimpulan. Data yang telah dianalisis kemudian diuji menggunakan triangulasi data. Triangulasi antarpeneliti, triangulasi metode, dan triangulasi sumber. Triangulasi dalam pengujian kredibilitas diartikan sebagai pengecekan dari berbagai sumber, baik menurut cara dan berdasarkan waktu (Creswell, 2007).

\section{Hasil dan Pembahasan}

\subsection{Dinamika dan Pengetahuan Lokal Keluarga Petani Miskin di Desa Ponteh}

Pemilihan Desa Ponteh secara administratif termasuk bagian dari Kecamatan Galis di wilayah Kabupaten Pamekasan. Pemukiman penduduk cenderung bergerombol dan seringkali terpisah jauh dari lahan pertanian. Sebagian besar penduduk Desa Ponteh menggantungkan hidupnya dari usaha pertanian. Angka statistik menunjukkan bahwa dari 2425 jiwa usia produktif, sekitar 77\%, bergerak dalam bidang pertanian. Namun, penduduk yang berprofesi sebagai buruh tani sebanyak 20,2\% (Profil Desa Ponteh Kecamatan Galis Kabupaten Pamekasan, 2020). Kondisi rendahnya persentase buruh tani memberikan penjelasan bahwa rumah tangga petani mengusahakan lahannya dengan tenaga kerja dari anggota keluarga sendiri. Para petani di Desa Ponteh hanya memanfaatkan buruh tani untuk pekerjaan yang membutuhkan penanganan cepat, misal contoh menyiangi rumput, menyemprot pestisida, dan mencangkul lahan pertanian.

Tingkat pendidikan masyarakat Desa Ponteh masih rendah, mayoritas masih didominasi lulusan Sekolah Dasar (SD). Rendahnya tingkat pendidikan penduduk Desa Ponteh berhubungan dengan beberapa faktor, antara lain; status sosial, status ekonomi, cara memandang pendidikan, dan faktor kebiasaan dalam masyarakat. Mengacu dari penjelasan informan dari rumah tangga petani, bahwa untuk menjadi petani tidak perlu sekolah tinggi. Menurut informan, yang berprofesi sebagai petani, sekolah hanya akan 
menghabiskan uang. Apalagi anak perempuan, yang akhirnya menjadi ibu rumah tangga untuk mengelola dapur. Selain itu, meskipun keinginan anak untuk melanjutkan pendidikan ada, kendala biaya dari orang tua menyebabkan anak tidak bisa melanjutkan sekolah. Saat ada kedua pilihan itu, orang tua lebih menginvestasikan untuk pertanian dari pada biaya pendidikan anaknya.

Kondisi pendidikan masyarakat akan mampu merubah pola pikir, perilaku, dan tindakan petani (Syarief, 2020). Keluarga petani miskin di Desa Ponteh mayoritas lulusan Sekolah Dasar (SD), sehingga berpengaruh terhadap pengetahuan dalam komoditas pertanian, efisiensi penggunaan lahan, penggunaan bibit unggul, penggunaan pupuk organik, dan sistem irigasi. Rendahnya tingkat pendidikan pada keluarga petani miskin ini lazimnya kurang memahami dan menguasai semua teknik usaha tani yang diperlukan guna mengelola kegiatan pertanian secara maksimal. Namun, meskipun keluarga petani miskin di Desa Ponteh tidak dapat menerapkan teknik usaha tani dengan optimal, mereka mampu bertahan di tengah pandemi Covid-19 secara sederhana dengan teknik lokal, nilai dan norma masyarakat, serta modal sosial.

Kehidupan sederhana dalam keluarga petani miskin di Desa Ponteh sebatas mengusahakan tanaman untuk konsumsi keluarga. Terkadang, hasil pertanian tidak mencukupi bagi kebutuhan konsumsi keluarga. Beban tanggungan ekonomi keluarga petani miskin di Desa Ponteh tidak lagi hanya bertanggung jawab secara ekonomi kebutuhan primer dan sekunder dari anggota keluarga ini saja, tetapi juga harus menambah anggota keluarga luas. Misal sepupu, karena dalam masyarakat Madura konteks keluarga tidak sebatas keluarga inti (sebatas orang tua dan anak), namun keluarga jauh (paman, sepupu dan lainnya), tetangga dekat juga masih menjadi tanggungan bersama (Kuntowijoyo, 2002).

Selama ini, keluarga petani miskin di Desa Ponteh tidak memiliki faktor produktif, kecuali pengerahan tenaga kerja. Setiap rumah tangga bahkan anggota keluarga, memiliki kesempatan guna mendapatkan pekerjaan dalam bidang pertanian. Terbatasnya luas lahan, terbatasnya aksesibilitas terhadap modal pertanian, sulitnya akses terhadap informasi dan komunikasi, memaksa keluarga untuk terlibat dalam kegiatan pertanian sebagai buruh tani. sampingan. Terdapat nilai dan norma yang masih dilestarikan pada keluarga petani miskin, misal pengerahan tenaga pertanian yang dilakukan secara bergantian. Lazimnya pengerjaan ini ditentukan pengerjaan lahan pertanian antara milik Bapak Ali, Bapak Bambang, Bapak Samsul. Saat mengerjakan lahan pertanian, baik mencangkul, menyiangi rumput, petani tidak menerapkan sistem bayaran, cukup menyediakan makanan, rokok, kopi, dan minuman. Terkadang, saat musim panen, petani membagikan kepada beberapa pekerja dalam bentuk hasil pertanian. Selain norma, modal sosial juga berkembang dalam keluarga petani miskin. Rasa saling percaya antar keluarga, aturan yang berkembang, serta jaringan yang dimiliki mampu memberikan manfaat saat pandemi. Pengenalan kondisi rumah tangga petani miskin merupakan tahap awal guna melihat kerentanan sosial ekonomi dan strategi adaptasi yang dilakukan selama pandemi Covid-19. 


\subsection{Kerentanan Sosial Ekonomi Keluarga Petani Miskin di Era Pandemi Covid-19}

Permasalahan Permasalahan Kerentanan merupakan suatu kondisi dari suatu komunitas atau masyarakat yang menyebabkan ketidakmampuan dalam menghadapi berbagai ancaman. Keluarga petani miskin di Desa Ponteh memiliki potensi kerentanan sosial ekonomi pada masa pandemi Covid-19. Hal ini disebabkan oleh dampak yang ditimbulkan dari pandemi Covid-19. Namun, berdasarkan hasil observasi, kerentanan sosial pada keluarga petani miskin di Desa Ponteh dalam bentuk kesehatan, persebaran Covid-19, kebencanaan lingkungan tidak terlalu terasa. Hal ini didasarkan dari hasil wawancara kelima informan, bahwa keluarga petani miskin di Desa Ponteh, secara sosial relatif kondusif dalam menghadapi pandemi Covid-19. Selama Pembatasan Sosial Berskala Besar (PSBB) hingga Pemberlakuan Pembatasan Kegiatan Masyarakat (PPKM) diberlakukan, kondisi masyarakat di Desa Ponteh masih tergolong normal. Petani tetap pergi ke ladang guna mengelola pertanian, begitu juga bidang pekerjaan lainnya.

Saat pemberlakuan pembatasan sosial, berbagai kegiatan masyarakat di Desa Ponteh tidak dapat dilakukan. Salah satunya adalah kegiatan kelompok tani yang sudah jarang bahkan ditiadakan pertemuannya. Kegiatan kelompok tani diisi dengan beberapa diskusi yang dilakukan melalui WhatsApp group (daring). Menurut informan penelitian, diskusi yang dilakukan secara daring melalui WhatsApp group memiliki banyak kekurangan, misal beberapa informan masih tidak paham teknologi. Selain itu, informasi yang dibagikan lewat WhatsApp group kurang optimal karena kurang terjadinya diskusi ketika ada petani yang tidak paham. Terganggunya dalam memperoleh informasi pertanian juga disebabkan oleh petugas lapang dan penyuluh pertanian dari pemerintah atau perusahaan swasta tidak lagi mengunjungi kelompok tani di Desa Ponteh.

Secara umum, kerentanan sosial keluarga petani miskin di Desa Ponteh adalah kesulitan aksesibilitas dalam memperoleh penghasilan yang sama seperti sebelum pandemi Covid-19. Seperti penjelasan Ibu Mita salah satu keluarga petani miskin saat diwawancarai di rumah beliau;

"...sebelum virus corona menyebar, saya biasanya berjualan sayur keliling, di Kota. Namu, sejak corona ini sudah tidak lagi. Jadi pendapatan untuk keluarga berkurang drastis"(Ibu Mita n.d.)

Kerentanan sosial masyarakat tinggi didasarkan pada tingkat mobilitas, khususnya ke kota. Seperti penjelasan informan Ibu Mita, pendapatan menurun drastis karena pembatasan sosial yang diberlakukan pemerintah. Selain aksesibilitas, keluarga petani miskin di Desa Ponteh masih bertumpu pada adat dan budaya dalam mengelola lahan pertanian. Kondisi ini mengakibatkan pemenuhan kebutuhan sehari-hari tidak mencukupi. Diperjelas dari hasil wawancara Bapak Bambang dan Bapak Samsul.

“...musim virus corona ini kami tetap menjalankan aktifitas pertanian sepertibiasa. Hanya saja hasil pertanian tidak cukup untuk memenuhi kebutuhan keluarga. Saya 
memiliki 4 tanggungan dalam keluarga. Sementara lahan yang saya usahakan kira-kira hanya 2000 meter persegi atau 1/5 hektar"(Bapak Bambang n.d.)

"...tambah susah ada virus corona ini, dek. Kami hanya menggantungkan kebutuhan hidup dari dari hasil pertanian. Hasil yang tidak menentu menjadi salah satu kendala, selain musim dan hama penyakit. Biasanya ada salah satu keluarga yang bekerja di Kota, tapi saat ini diliburkan"(Bapak Samsul n.d.)

Keluarga petani miskin di Desa Ponteh selama masa pandemi Covid-19 sangat menggantungkan diri pada hasil pertanian. Pembatasan sosial mengakibatkan ruang gerak dari keluarga petani miskin menjadi terbatas. Sebelum pandemi, terdapat anggota keluarga yang bekerja di luar pertanian. Misal Bapak Affan yang bekerja sebagai penjaga rumah makan di kota. Saat pembatasan sosial, rumah makan ditutup, sehingga Bapak Affan kembali bekerja dalam bidang pertanian. Sehingga pendapatan keluarga hanya dari kegiatan pertanian. Begitu juga yang terjadi pada keluarga Ibu Anik, yang sebelum pandemi melanda bekerja sebagai pedagang jamu keliling di kota. Saat pandemi, hasil penjualan menurun drastis dari biasanya. Ibu Anik kembali membantu suami di ladang guna menyambung kehidupan. Sehingga kerentanan sosial ekonomi di masa pandemi Covid-19 meningkat, khususnya dalam bidang aksesibilitas dan mobilitas masyarakat.

Berdasarkan dari konteks di atas, dapat dipaparkan bahwa kerentanan sosial mengandung dimensi struktur atau kelembagaan sosial. Saat kerentanan sosial dikaitkan dengan pandemi Covid-19, kerentanan sosial dimaksudkan ketidakmampuan individu, keluarga, lembaga, masyarakat dalam menghadapi ancaman penyakit, sosial, dan ekonomi. Pada keluarga petani miskin di Desa Ponteh, ketidakmampuan dan ketidaksiapan dalam menghadapi pandemi Covid-19 saat awal kejadian. Lebih lanjut, guna memahami kerentanan sosial ekonomi lebih berfokus pada aspek kemampuan masyarakat dalam mengatasi dampak yang diakibatkan (Musa et al., 2021). Berbagai cara guna meminimalisir dampak dari pandemi atau ancaman lain, dengan cara menempatkan, mengatur, dan menetapkan karakteristik masyarakat atau individu sesuai dengan kapasitas dan kapabilitas yang dimiliki (Blaikie et al., 1994).

\subsection{Strategi Adaptasi Keluarga Petani Miskin Selama Pandemi Covid-19}

Menurut Studi strategi adaptasi keluarga petani miskin terfokus pada cara untuk beradaptasi dengan perubahan kondisi, baik di dalam pertanian atau di luar pertanian berupa faktor sosial ekonomi. Keluarga petani miskin, terutama di perdesaan telah menunjukkan bahwa ketahanan, adaptasi pertanian dapat dipengaruhi oleh, pengetahuan lokal, sumber daya yang tersedia guna mendukung kegiatan pertanian, beban kerja, serta struktur masyarakat.

Konsep strategi adaptasi adalah kemampuan, kekuatan, ketahanan individu atau kelompok dalam masyarakat selama pandemi Covid-19. Begitu juga keluarga petani miskin saat menghadapi kondisi sulit akibat pandemi. strategi adaptasi keluarga petani miskin masih bergantung pada orang tua, saudara atau kerabat dekat dalam pemenuhan 
Kerentanan Sosial Ekonomi dan Strategi Adaptasi Keluarga Petani Miskin Selama| Pandemi Covid-19: Kasus dari Madura

kebutuhan, terutama kebutuhan pokok yaitu beras atau jagung. Seperti penjelasan Ibu Anik salah satu keluarga petani miskin:

"...kami baru menikah selama tiga tahun, baru dikaruniai anak yang masih umur 8 bulan. selama musim tanam, suami bekerja di ladang, saat menunggu panes biasanya suami bekerja sebagai buruh serabutan. Namun corona ini mengakibatkan pekerjaan di luar pertanian menjadi sedikit dan bahkan sulit. Jadi kami untuk makanan khususnya beras diberikan oleh orang tua"(Ibu Anik n.d.)

Penjelasan ini menunjukkan bahwa keluarga petani miskin masih bergantung pada orang tua. Lazimnya dialami oleh keluarga yang baru menikah, belum memiliki penghasilan yang memadai (kecukupan), yang tergolong belum sepenuhnya mapan. Dalam masyarakat Madura, bantuan kebutuhan pokok berupa beras atau jagung dari orang tua kepada anaknya merupakan hal yang wajar. Pertama, karena lahan pertanian masih dikelola oleh orang tua, anak atau menantu hanya sebagai tenaga pembantu. Kedua, dalam masyarakat Madura, keluarga yang masih baru menikah meskipun tidak tinggal dalam satu rumah tetap diawasi dan dijaga tingkat kesejahteraannya. Selain hasil pertanian berupa beras atau jagung, ikan, sayur serta kebutuhan primer lainnya sesekali juga diperhatikan oleh orang tua. Setidaknya setiap keluarga petani miskin memanfaatkan ikatan keluarga yang sangat kuat. Sehingga bantuan orang tua sebagai sumber nafkah penunjang, kini menjadi sumber pokok yang digunakan untuk memenuhi kebutuhan hidup sehari-hari selama masa pandemi Covid-19.

Keluarga petani miskin di Desa Ponteh secara sosial masih mempertahankan nilai tradisi masyarakat Madura. Nilai budaya yang masih dijaga dan dilestarikan oleh keluarga petani miskin di Desa Ponteh adalah nilai kejujuran, tolong menolong, kekeluargaan, keterbukaan, keramahan, kesederhanaan, dan kesungguhan (keseriusan). Bentuk keramahan terlihat pada sikap keluarga petani miskin yang "roco"(mudah akrab). Selain nilai budaya, terdapat pola pikir yang menjadi karakter masyarakat Madura dalam menghadapi pandemi Covid-19. Karakter masyarakat Madura diantaranya; berjiwa keras, ulet menjalani hidup, pemberani, menjunjung tinggi harga diri dan martabat keluarga. Seperti penjelasan Bapak Bambang, salah satu keluarga petani miskin di Desa Ponteh:

"...selama musim tanam, beberapa hal masih menerapkan konsep tolong menolong. Hal ini dijelaskan karena sejak dulu masih dipertahankan. Hal ini juga berlaku dalam bidang lainnya, seperti membangun rumah, kegiatan bersih-bersih lingkungan” (Bapak Bambang n.d.)

Diperjelas oleh pemaparan Bapak Affan:

"...saat bekerja, konsep kekeluargaan masih menjadi hal yang utama dalam lingkungan masyarakat kita. Saling keterbukaan ketika ada masalah, keramahan, kesederhanaan, dan kesungguhan (keseriusan) dalam bekerja. Kebiasaan ini masih dipertahankan oleh masyarakat kita. Apalagi sejak adanya pandemi Covid-19 ini, jadi harus kompak menghadapinya. Kadang kami berbagi makanan ketika ada tetangga dekat atau keluarga sedang tidak makan"(Bapak Affan n.d.) 
Beberapa langkah yang dilakukan keluarga petani miskin dalam menghadapi dampak pandemi Covid-19. Mereka membangun solidaritas kelompok sesuai nilai dan norma yang berkebang, misal contoh gotong-royong, saling membantu dalam bentuk berbagi makanan atau kebutuhan pokok. Rasa saling "peduli" merupakan nilai kekeluargaan yang menjadi salah satu indikator dalam menghadapi dampak pandemi. Nilai kekeluargaan ini terlihat dalam kehidupan keseharian petani yang suka berkumpul, baik saat bekerja atau tidak bekerja. Hal ini terwujud bentuk gotong-royong (biasanya gotong royong memperbaiki rumah warga, fasilitas umum). Berikutnya adalah berbalas jasa tenaga/barter kerja, lazimnya bersifat pribadi dan bidang yang produktif. Masyarakat menyebut "males tengka". Jadi ketika ada bantuan yang diberikan oleh salah satu masyarakat tanpa imbalan, maka secara tidak langsung yang dibantu memiliki kewajiban untuk berbalas jasa. Misal dalam balas jasa garapan lahan pertanian. Selanjutnya adalah tolong-menolong, lazimnya bersifat sosial seperti ketika ada musibah kematian, acara pernikahan, hajatan warga dan kegiatan sosial kemasyarakatan lainnya.

Pandemi Covid-19 mengakibatkan keselarasan kehidupan bermasyarakat di perdesaan. Dalam konteks kehidupan keluarga petani miskin, keselarasan yang terbentuk akibat pandemi menghasilkan sebuah kohesi yang keberlanjutan. Kohesitas dan solidaritas sosial masyarakat yang berdasarkan konteks lokal mampu menanganinya secara bersama dalam menghadapi situasi serta kondisi yang sulit dan bermasalah (Irfan, 2017). Nilai dan norma yang menghasilkan kohesi dan solidaritas sosial secara substantif memasukkan nilai-nilai kejujuran, pemenuhan tugas, dan kesediaan untuk saling menolong. Sehingga keluarga petani miskin di masa pandemi Covid-19 tidak sepenuhnya menggantungkan diri modal manusia, modal alam, teknologi, kelembagaan. Namun juga mampu bertahan melalui nilai dan norma yang menghasilkan kohesi dan solidaritas sosial dalam masyarakat (Mangkuprawira, 2019).

Selain ikatan keluarga dan modal sosial masyarakat, tanggapan yang dilakukan oleh keluarga petani miskin di Desa Ponteh meminimalkan pengeluaran rumah tangga dan memanfaatkan jaringan sosial. Seperti penjelasan Bapak Samsul:

“...saya menghubungi teman-teman di desa tetangga untuk menjual hasil pertanian berupa sayuran. Dengan dijual kepada teman-teman lebih mudah, serta enak langsung diantarkan ke rumahnya. Kadang saya mencari pemasukan lain dengan berbagai macam usaha lain"(Bapak Samsul n.d.)

Sementara penjelasan Ibu Mita fokus pada pengeluaran rumah tangga:

"...selama pandemi Covid-19 pendapatan untuk konsumsi rumah tangga menurun, jadi saya mengalokasikan untuk belanja dapur diminimalkan. Yang penting ada untuk makanan. Biasanya sebelum pandemi saya membeli lauk ayam, telur seminggu dua kali. Namun setelah pandemi hanya tahu, tempe, dapat dikategorikan jarang membeli daging”(Ibu Mita n.d.)

Dari pemaparan informan di atas, jaringan sosial dapat bermanfaat guna meminimalkan dampak pandemi Covid-19. Petani memanfaatkan jaringan sosial guna 
meningkatkan penjualan hasil pertanian. Selain dalam bentuk pemasaran, jaringan sosial juga digunakan untuk mencari peluang usaha supaya kebutuhan rumah tangga terpenuhi. Selain itu, bagi ibu rumah tangga menemukan upaya dengan meminimalkan konsumsi rumah tangga. Dalam konteks sosial, pilihan rasional keluarga petani miskin di Desa Ponteh sebagai strategi bertahan hidup. Lebih lanjut, petani sebagai aktor juga memiliki tindakan sebagai upaya guna mencapai tujuan tersebut, misal pemilihan bahan makanan untuk konsumsi rumah tangga. Petani juga dipandang memiliki pilihan, nilai dan keperluan sesuai dengan kebutuhan individu atau keluarga petani miskin di perdesaan. Aktor yang melakukan pilihan, serta tindakan menggunakan alasan tersendiri, misal karena ingin hemat, serta kebutuhan untuk konsumsi rumah tangga tetap terpenuhi. Pilihan rasional ini sesuai dengan tujuan dan manfaat yang diperoleh dari meminimalkan pengeluaran untuk konsumsi rumah tangga (Ritzer et al., 2010).

\section{Kesimpulan dan Saran}

Pemilihan Pemilihan Pandemi Covid-19 yang terjadi hingga saat ini menjadi tantangan bersama. Studi ini menjelaskan bahwa keluarga petani miskin di Desa Ponteh secara sosial relatif kondusif dalam menghadapi pandemi. Keluarga petani miskin mengalami kerentanan sosial ekonomi dalam bentuk kesehatan, persebaran Covid-19, kebencanaan lingkungan. Secara umum, kerentanan sosial yang dihadapi adalah kesulitan mobilitas dan aksesibilitas dalam memperoleh penghasilan yang sama seperti sebelum pandemi. Seperti penjelasan salah satu informan pendapatan menurun drastis karena pembatasan sosial yang diberlakukan pemerintah. Para keluarga petani miskin tidak mengalami dampak berkepanjangan dari pandemi karena mereka mempunyai kemampuan pengelolaan dalam masa sulit. Salah satu contoh adalah keluarga petani miskin di Desa Ponteh masih bertumpu pada adat dan budaya dalam mengelola lahan pertanian. Pengetahuan lokal ini menjadi kekuatan keluarga petani miskin di perdesaan Madura dalam menghadapi dampak pandemi Covid-19.

Penelitian ini menunjukkan bahwa strategi adaptasi yang dilakukan oleh para keluarga petani miskin di perdesaan Madura dalam menghadapi dampak pandemi Covid19; pertama, membangun solidaritas kelompok sesuai nilai dan norma yang berkembang, misal contoh gotong-royong, saling membantu dalam bentuk berbagi makanan atau kebutuhan pokok. Rasa saling "peduli" merupakan nilai kekeluargaan yang menjadi salah satu indikator dalam menghadapi dampak pandemi. Kedua, setiap keluarga petani miskin memanfaatkan ikatan keluarga yang sangat kuat. Keluarga petani miskin masih bergantung pada orang tua, saudara atau kerabat dekat dalam pemenuhan kebutuhan, terutama kebutuhan pokok yaitu beras atau jagung. Sehingga bantuan orang tua sebagai sumber nafkah penunjang, kini menjadi sumber pokok yang digunakan untuk memenuhi kebutuhan hidup selama masa pandemi. Ketiga, keluarga petani miskin di Desa Ponteh meminimalkan pengeluaran rumah tangga dan memanfaatkan jaringan sosial. Hasil 
penelitian ini memberikan tanggapan bahwa keluarga petani miskin di perdesaan mampu bertahan dan berkembang dalam menghadapi dampak pandemi Covid-19.

\section{Daftar Pustaka}

A'dani, F., Sukayat, Y., Setiawan, I., \& Judawinata, M. G. (2021). Pandemi Covid-19: Keterpurukan dan Kebangkitan Pertanian Strategi Mempertahankan Ketersediaan Pangan Pokok Rumah Tangga Petani Padi Pada Masa Pandemi Covid-19 (Studi Kasus: Desa Pelem, Kecamatan Gabus, Kabupaten Grobogan, Jawa Tengah). Mimbar Agribisnis: Jurnal Pemikiran Masyarakat Ilmiah Berwawasan Agribisnis, 71), 309-319. https://doi.org/10.25157/ma.v7i1.4529

Arifin, B. (2021). Pertanian Bantalan Resesi: Resiliensi Sektor selama Pandemi Covid-19. INDEF.

Blaikie, P., Cannon, T., Davis, I., \& Winner, B. (1994). At risk: Natural hazards, people's vulnerability and disasters. Routledge.

Bryce, C., Ring, P., Ashby, S., \& Wardman, J. K. (2020). Resilience in the face of uncertainty: Early lessons from the COVID-19 pandemic. Journal of Risk Research, 23(7-8), 880887. https://doi.org/10.1080/13669877.2020.1756379

Creswell, J. W. (2007). Qualitative inquiry and research method: Choosing among five approaches. Sage Publications.

Darnhofer, I. (2020). Farm resilience in the face of the unexpected: Lessons from the COVID19 pandemic. Agriculture and Human Values, 1-2. https://doi.org/10.1007/s10460020-10053-5

Filofa, C. M. M., \& Yamin, M. (2021). Dampak Covid-19 Terhadap Perubahan Perilaku Sosial dan Ekonomi Petani Miskin Dalam Mengembangkan Usahatani Padi di Kelurahan Keramasan Kecamatan Kertapati [Undergraduate, Sriwijaya University]. https://repository.unsri.ac.id/55182/

Irfan, M. (2017). Metamorfosis Gotong Royong Dalam Pandangan Kontruksi Sosial. Prosiding Penelitian dan Pengabdian kepada Masyarakat, 4(1), 1-10. https://doi.org/10.24198/jppm.v4i1.14204

Kuntowijoyo. (2002). Perubahan Sosial dalam Masyarakat Agraris Madura 1850-1940. Mata Bangsa.

Kurniawansyah, H., Amrullah, A., Salahuddin, M., Muslim, M., \& Nurhidayati, S. (2020). Konsep Kebijakan Strategis Dalam Menangani Eksternalitas Ekonomi dari Covid-19 Pada Masyarakat Rentan di Indonesia. Indonesian Journal of Social Sciences and Humanities, 1(2), 130-139.

Mangkuprawira, S. (2019). Strategi Peningkatan Kapasitas Modal Sosial dan Kualitas Sumber Daya Manusia Pendamping Pembangunan Pertanian. Forum Penelitian Agro Ekonomi; Vol 28, No 1 (2010): Forum Penelitian Agro Ekonomi; 19-34. https://doi.org/10.21082/fae.v28n1.2010.19-34 
Miles, M. B., Huberman, A. M., \& Saldana, J. (2014). Qualitative Data Analysis, A Methods Sourcebook (3rd ed.). Sage Publications. Terjemahan Tjetjep Rohindi Rohidi, UI-Press.

Musa, P., Suryadi, A., \& Paramitha, R. R. (2021). Kerentanan Sosial dan Ekonomi Masyarakat di Perbatasan Kabupaten Sambas Menghadapi Pandemi Covid-19. Jurnal Muara Ilmu Sosial, Humaniora, dan Seni, 5(1), https://doi.org/10.24912/jmishumsen.v5i1.10032.2021

Penkler, M., Müller, R., Kenney, M., \& Hanson, M. (2020). Back to normal? Building community resilience after COVID-19. The Lancet Diabetes \& Endocrinology, 8(8), 664665. https://doi.org/10.1016/S2213-8587(20)30237-0

Pontoan, K. A., Merung, Y. A., Kelana, G., \& Lengkong, M. R. (2021). Peningkatan Kapasitas Petani pada Masa Pandemi COVID-19 Melalui Pelatihan Manajemen Keuangan \& Pemasaran Digital. COMSERVA: Jurnal Penelitian Dan Pengabdian Masyarakat, 1(5), 178-186. https://doi.org/10.36418/comserva.v1i5.28

Prime, H., Wade, M., \& Browne, D. T. (2020). Risk and resilience in family well-being during the COVID-19 pandemic. American Psychologist, 75(5), 631-643. https://doi.org/10.1037/amp0000660

Profil Desa Ponteh Kecamatan Galis Kabupaten Pamekasan. (2020).

Ritzer, G., Douglas, J., \& Goodman. (2010). Teori Sosiologi Modern. Kencana.

Satriyati, E., \& Biroli, A. (2021). Kembali ke Rempah: Upaya Rumah Tangga Petani di Bangkalan Guna Peningkatan Kesehatan dan Penanggulangan Kemiskinan selama Pandemi Covid-19. Prosiding Seminar Nasional Penanggulangan Kemiskinan, 1(1), Article

https://conference.trunojoyo.ac.id/pub/index.php/semnaspk/article/view/45

Sudaryanto, T., \& Suharyono, S. (2020). Peningkatan Daya Tahan Petani dan Usaha Tani Terhadap Pandemi Covid-19. In Dampak Pandemi Covid-19: Perspektif Adaptasi dan Resiliensi Sosial Ekonomi Pertanian. IAARD Press.

Sugiyono. (2016). Metode Penelitian Kuantitatif Kualitatif dan R\&D. Alfabeta.

Sunarti, E. (2021). Ketahanan Keluarga Indonesia di Masa Pandemi Covid 19. IPB Press.

Syarief, Y. A. (2020). Kajian Proses Pembelajaran dalam Penyuluhan Pertanian untuk Meningkatkan Kompetensi Kewirausahaan Petani Jagung Di Kabupaten Grobogan Provinsi Jawa Tengah. Agritech: Jurnal Fakultas Pertanian Universitas Muhammadiyah Purwokerto, 21(2), 101-108. https://doi.org/10.30595/agritech.v21i2.3484 